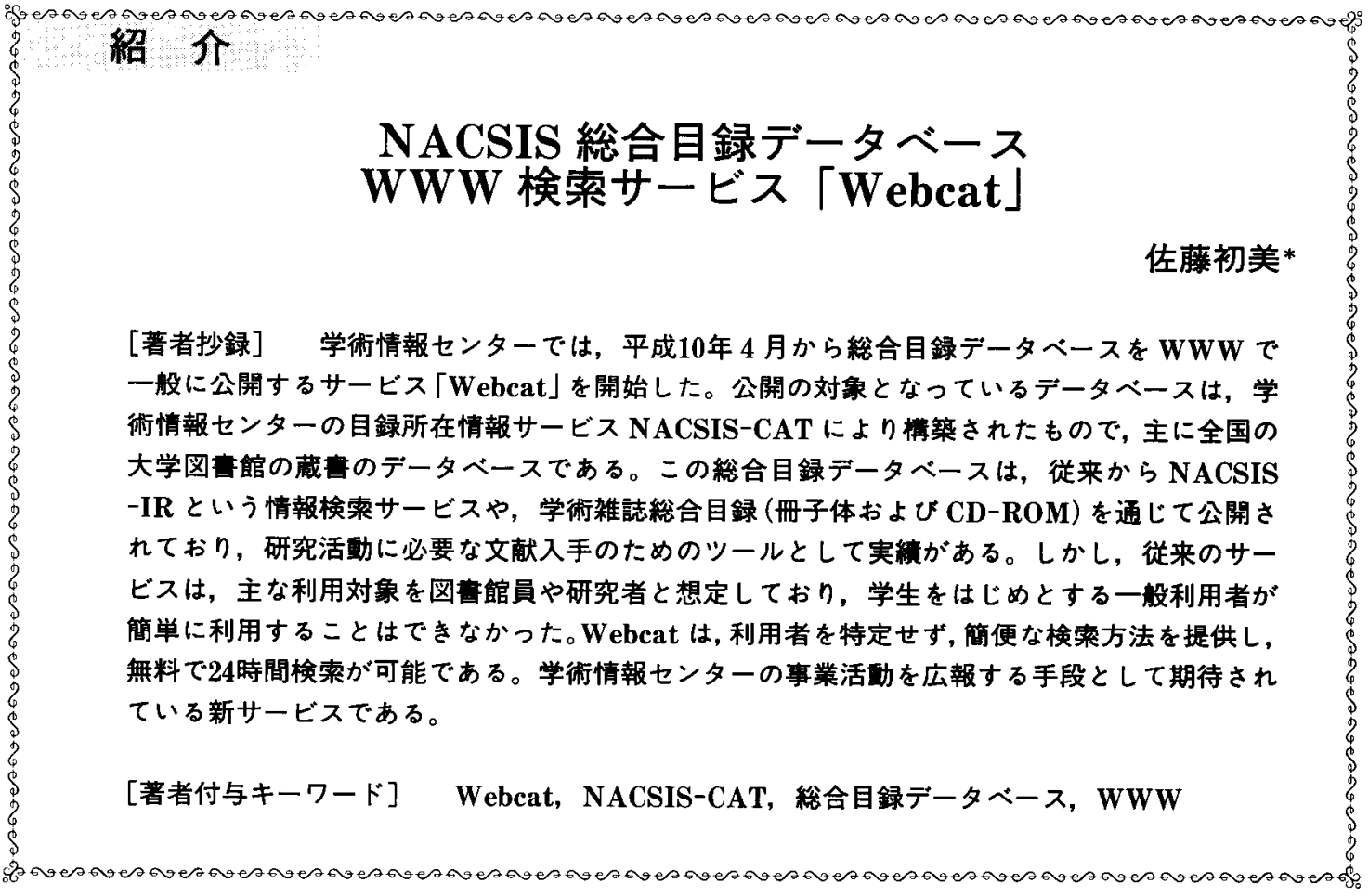

Introductory article

\title{
Retrieval service for NACSIS-CAT Database on World Wide Web "Webcat"
}

SATO Hatsumi

\begin{abstract}
[Author Abstract] NACSIS (NAtional Center for Science Information Systems) started new service from Apr. 1998, called "Webcat". Webcat is the service to offer union catalog database via WWW. This database is constructed by online cataloging system "NACSIS-CAT", which members are mainly university libraries. We offer this database by our information retrieval service "NACSIS-IR" and "Union catalog of serials (printed form and CD-ROM)". These services are useful to find out materials needed. But, these users are limited to librarians and researchers. The features of Webcat are free access, free charge, and easy searching. We hope that Webcat will be advertisement service for NACSIS's work.
\end{abstract}

[Keywords by Author] Webcat, NACSIS-CAT, union catalog database, WWW

* 学術情報センタ一事業部目録情報課（テ112-8640 文京区大塚3-29-1）

Tel. 03(3942)6984 E-mail : sato@op.nacsis.ac.jp

Catalog Information Division, Operations Department, National Center for Science Information Systems (29-1, Otsuka 3-chome, Bunkyo-ku, Tokyo, 112-8640) 


\section{1. 学術情報センターのサービス}

本稿で紹介するWebcat (http://webcat.nac sis.ac.jp/) は，WWW 上で目録所在情報（どのよ うな図書・雑誌がどの図書館にあるか）を一般に 無償で提供するサービスである。検索できるデ一 夕は, 図書·雑誌合わせて書誌データが約 400 万件, 所蔵データは約 3,600 万件である(平成10年 8 月現 在)。これらのデータは, NACSIS-CAT という目 録システムにより構築されたものであり，Webcatのみではなく, 学術情報センター(以下 NACSIS : NAtional Center for Science Information Systems）の他のサービスによっても提供されて いる。そのため, NACSIS-CATを含め, NACSIS の主なサービスについてもあらかじめ簡単に紹介 しておく。

NACSIS は，学術情報の収集，整理および提供 並びに学術情報㧍よび学術情報システムに関する 総合的な研究扔よび開発を行う目的で, 昭和61年 4 月に設置された大学共同利用機関である1。こ れらの目的に沿うべく，これまで以下のような サービスを行ってきている。

NACSIS-CAT は, 全国の大学図書館, 短期大 学・高等専門学校の図書館をはじめ, 国公立研究 機関，公共図書館などをネットワークで結び，共 同で総合目録データベースを構筑するオンライン 目録システムで, 平成10年でサービス開始14年目 を迎えた。そこで蓄積されたデー夕は，表 1 の NACSIS-IR という種々のデータベースを研究者 向けに提供している情報検索サービスで, 従来か ら提供しており，多くの利用実績を持っている。 また，常に最新の所蔵情報が参照できるため，資
料相互貸借のための图書館業務向けのサービスで あるNACSIS-ILLでも利用されている。さらに， 雑誌デー夕を冊子体㧍よび CD-ROMに編集し， 学術雑誌総合目録として刊行している。

\section{Webcat 公開まで}

NACSISの最も新しいサービスとして，Webcatの正式サービスを開始したのは，平成10年 4 月である。このサービスの登場は次のような背景 からである。

従来より，目録所在情報は研究活動において非 常に重要な位置を占めていた。これまでのサービ スでは, 利用するためには申請が必要であり, 利 用者の範囲にも制限が苛った。例之ば，NACSIS -CAT, NACSIS-ILLは図書館業務用システムで あるため，図書館という機関をサービス対象とし， 利用するには特別なソフトウエアが必要であっ た。また, NACSIS-IR は研究者向けの情報検索 サービスであることから, 学部学生などが利用者 の対象とはなっていなかった。

これらのシステムでは, 申請方式を採用するこ とにより，利用者を把握することができたため， 利用講習会等を開催することによって, 以下のこ とが可能であった。

・データベース形成において

適切な操作, 入力基準の周知

↔質のよいデータの入力

・検索において

高度な検索手段の提供

$\Rightarrow$ 的確な情報を効率的に引き出す

したがって，ある程度操作に習熟が必要なこれ

表 1 サービスー覧

\begin{tabular}{|c|c|c|c|}
\hline サービ & サービス略妳 & 利用対象 & サービス開始年 \\
\hline 目録所在情報サ- & NACSIS-CAT & 大学図寁館等 & 1984.12 \\
\hline & NACSIS-ILL & 大学图毒館等 & 1992. 4 \\
\hline 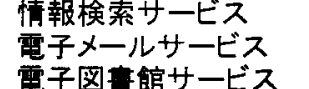 & $\begin{array}{l}\text { NACSIS-IR } \\
\text { NACSIS-MAIL } \\
\text { NACSIS-ELS }\end{array}$ & 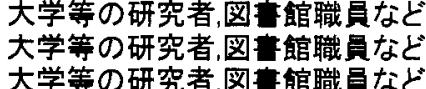 & $\begin{array}{l}\text { 1987. } 4 \\
1988.4 \\
1997.4\end{array}$ \\
\hline
\end{tabular}


らのサービスを，そのまま不特定多数の利用者に 公開することは適当ではなかった。

しかし，総合目録データベースは, NACSISが 運用しているデータベースのうち，提供するデ一 夕の内容が研究分野等を選ばない基礎的な目録所 在情報であることから, 潜在的な需要が多いと見 込まれていた。これを, 利用資格なし, 簡単な操 作, 特別なソフトウエア不要という条件で一般に 公開した場合, 学術情報の提供という NACSIS の事業目的が効果的に実現されるであろうことが 予想された。またここのサ一ビスの利用が広がれ ば, NACSISの事業そのものの広報にもなり, 他 のサービスへの利用を呼び込むものとして機能す ることも期待された。もともと，総合目録デー夕 ベースのすへてのデータは，各図書館が作成した ものでもあり，作成者八の還元の意味においても， 公開すれば，図書館のレファレンス業務を軽減さ せる可能性があるとも考えられた。

一方, Internet 八の接続が, そのブラウザととも に普及しはじめていた。時期的には Windows95 が登場したころであり，ブラウザが標準装備され ていたことで普及の加速度が増した。民間の Internet 接続プロバイダも増加し，その利用価格 に競争が及んだことも普及要因の一つと考えられ る。Web上での各図書館の OPACの公開も次々 と始まっており，資料の所在について Internet で 検索することが国内外で有効な手段の一つとなっ ていた。Internet 上に公開することは、データの国 外への公開にもなり, 当時要求されていた日本情 報の公開という問題への一つの封処ともなる。同 時期に，NACSIS でのシステム改訂 (平成 9 年 1 月）にともない，データベースをUNIXサーー゙上 で扱うことが可能となり，システム環境において も, WWW でのデータベース公開へ向けての条件 が揃っていった。

公開の準備を整える段階で, 24時間検索可能, 利用制限なし, 簡便な検索力法の提供などを Webcatのコンセプトとすることにした。次に，そ の機能やマシンへの負荷を検証するため, 平成 9 年 4 月から試行サービスを行った。これまで,
NACSISが行ってきたどのサービスとも異なり， 申請や利用对象者の制限がなく，誰でもいつでも どのようにでも利用できるため，どの程度利用が あるのかが明確でなかった。公開直後から重い負 荷がかかるのを防ぐよう配虑し, 約 1 年かけて, 機能の改訂，バグをつぶす作業，NACSISの他の サ一ビスなどへの影響調査，負荷の状況の把握な どを行い，問題がないことを見極めた上で，正式 運用への切り替之を行った。

\section{Webcat の内容と機能}

\section{1 データベースの内容}

Webcat で検索できるデータベースの内容の詳 細と, 増加するデー夕数および参加困書館内訳は 表 2 表 4 に示すとおりである2)。

登録されているデータは，刊行される形態の違 いのみで図書と雑誌にわかれているが, 資料の夕 イプは問わない。したがって，印刷形態のほかに，

表 2 総合目録データベースのデータ件数

\begin{tabular}{|c|c|c|}
\hline & （平成10年8月 & 7日現在） \\
\hline データの程䅡 & 図 和洋) & 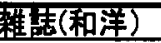 \\
\hline $\begin{array}{l}\text { 宰憙情報 } \\
\text { 所蔵情報 }\end{array}$ & $\begin{array}{r}3,785,693 \\
34,120,648\end{array}$ & $\begin{array}{r}218,292 \\
3,247,702\end{array}$ \\
\hline
\end{tabular}

表 3 増加するデータ数

\begin{tabular}{|c|c|c|}
\hline データの種類 & 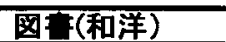 & 雑誌(和洋) \\
\hline $\begin{array}{l}\text { 誌情報 } \\
\text { 所荿情報 }\end{array}$ & $\begin{array}{l}\text { 約10,000件/週 } \\
\text { 約100,000件/過 }\end{array}$ & $\begin{array}{l}\text { 約200件/䓢 } \\
\text { 約 } 2,000 \text { 件/週 }\end{array}$ \\
\hline
\end{tabular}

表 4 参加図書館内訳

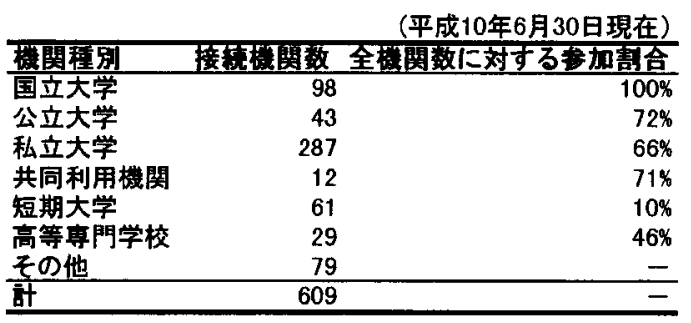


マイクロ資料, 地図, CD-ROM, 映像資料等が含 まれる。

登録する資料の範囲は，各図書館の方針による ため, 登録されているデータ=所蔵している資料 すべてではない。しかし, 参加している図書館に おいては，新規に受け入れた資料の登録のみでな く、いわゆる溯及入力(過去に遡って入力作業を行 うこと)も年々進行し，登録されている資料の所蔵 資料に占为る割合はさらに大きくなりつつある。

参加図書館は, オンラインで接続されている館 のみだと表4のとおりだが，データを登録してい る图書館という意味であれば，数は異なる。これ は, 総合目録データベースの雑誌部分は, 昭和 28 年から文部省が編集してきた[学術雑誌総合目録」 の編集事業を引き継いでいるからでありオンラ イン以外の力法でもデータを寄せていただいてい る3)。数年に一度, 全国調查を行っているが, 現在 編集中の1998年版欧文編では, 1,200以上の図書館 （オンライン接続館含む）から雑誌の所蔵状況に 関するデータを収集している。

\section{2 Webcat の画面構成および検索の流れ}

(1) 検索画面（図 1)

図 1 は Webcatの初期画面であり，検索キーを 入力する画面である。例として, 著者名「ふじの ゆき打」を指定する。漢字でも，ローマ字でもよ い。また，キ一の来尾に「*」を指定することに よって, 前方一致も指定できる。日本譀以外の言 語の場合，冠詞，接続詞などは指定できない。こ れはWebcatでのみ制限されている事項で, NACSIS-CAT，NACSIS-IR ではシステムが自 動的に除いてくれるようになっている。

逆に, NACSIS-CATにはなく, Webcatでのみ 奏現されている機能としては，口ーマ字からの検 素がある。データベースで持っているインデクス は，目録のデータとして登録されたもののみ(和 資料なら漢字，ひらがな，力夕カ十等。洋資料な らアルファベット等) なので，ローマ字のヨミは 通常付与されておらず，そのインデクスも当然な がら持っていない。しかし，Webcatでは日本語入
力機能を持たないコンピュータからも検索ができ るよう，ローマ字で入力されたキーワードに対す る変換機能を備之ている。

入力の仕方がわからない時は，「利用の手引き」 を参照子ることができる((4)を参照)。

（2）簡略表示画面（図 2 )

著者名に「ふじのゆきお」を含む書誌データが 簡略表示される。各書誌は，クリックすることで 詳細表示および所蔵する四書館の情報を表示する ことができる。

実際の検索においては，いくつか注意点もある。 システムの負荷を考慮し，検索条件に該当する書 誌データが200件以上あった場合は，現在は200件 までで表示を制限している。特定のデー夕を挆す 場合は，さらにキーワードを追加するなどして検 索結果を小さくすることが必要であるし，公く文 献の情報を収集する目的であっても，研究者向け の NACSIS-IRのように高度な検索機能が実現 されているわけではないので，七ット件数が多く なればなる汪ど，いわゆる/イズが発生しやすく なる。

（3）詳細表示および所蔵館表示画面（図 3 ）

資料の書誌データの詳細表示と，その資料を所 蔵する図書館数および一覧が表示される。書誌 データは，シリーズ名をクリックすることで，各 巻の書誌デー夕を表示することができる。㮅誌で あればそそのタトルの変要関係にある書誌を， 同様にクリックして表示することができる。所蔵 データの内容は，図書館の略称，請求記号等であ る。所蔵デ一夕は, 図書館の略称順に全件表示さ れる。各闵書館の略称をクリックすることで，四 書館の正式名称, 所在地, 電話番号等を表示する ことができる。

(4)利用の手引き（図 4)

検索方法, 検索の注意点等については, 利用の 手引きを参照することができる。英語版もある。

（5）英語版検索画面（図 5)

English manual をクリックすることで, 検索の 万法，資料そのものの入手に関する注意事項を参 照することができる。 


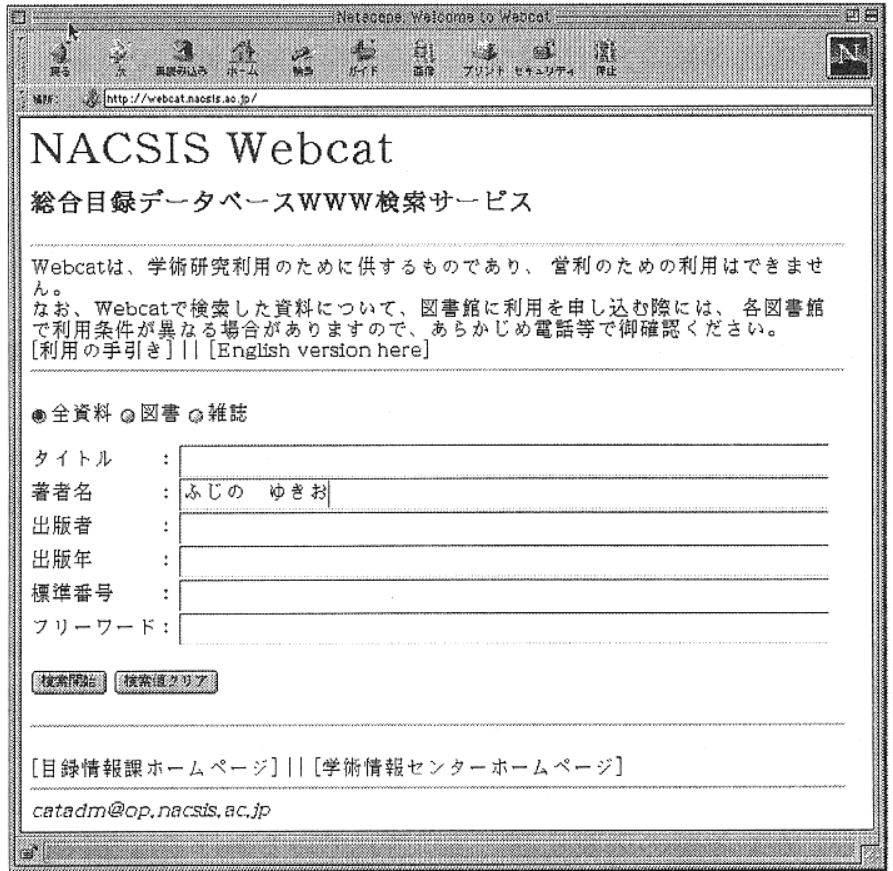

図 1 検索画面

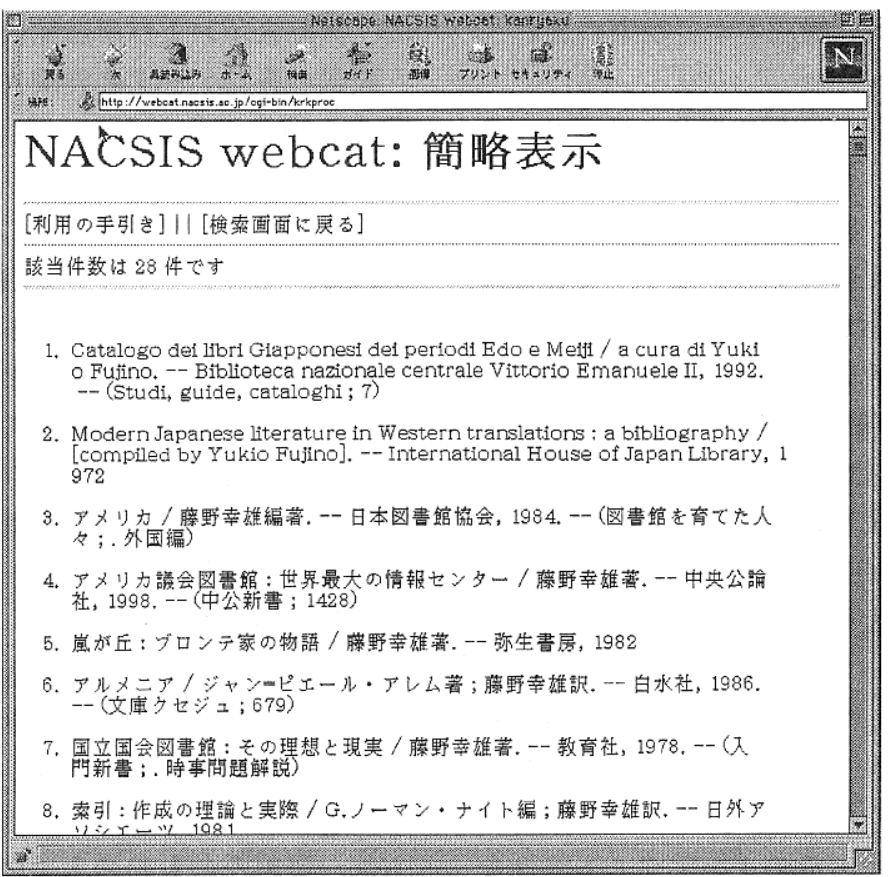

図 2 簡略表示 


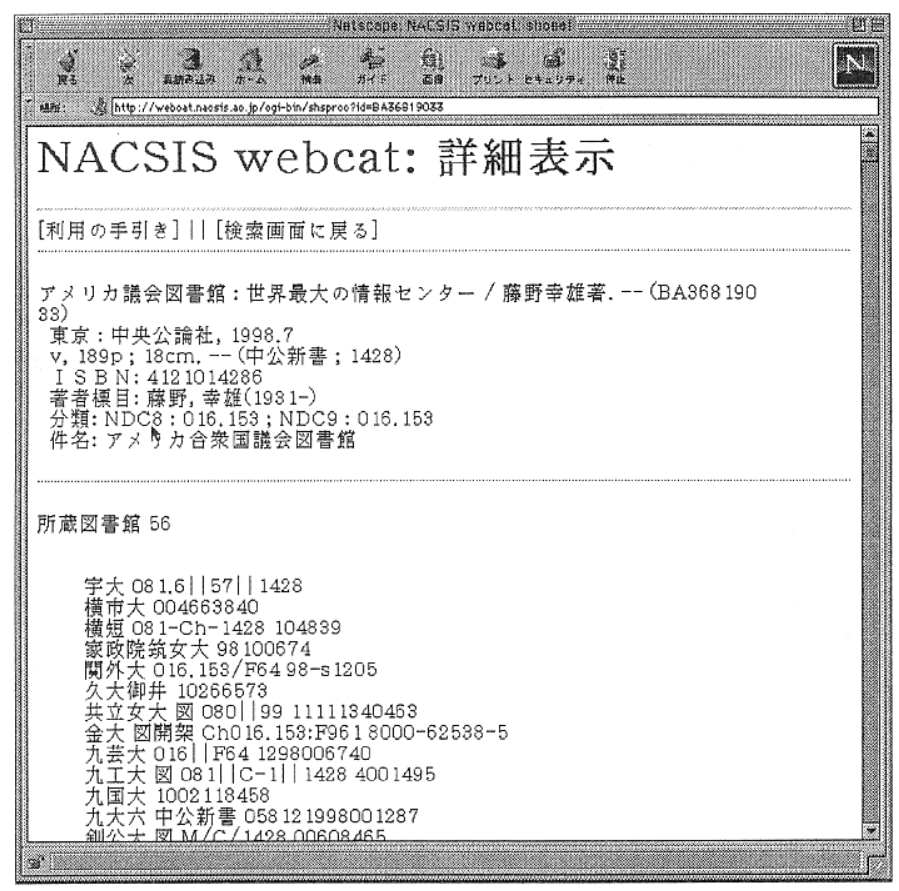

図 3 詳細表示

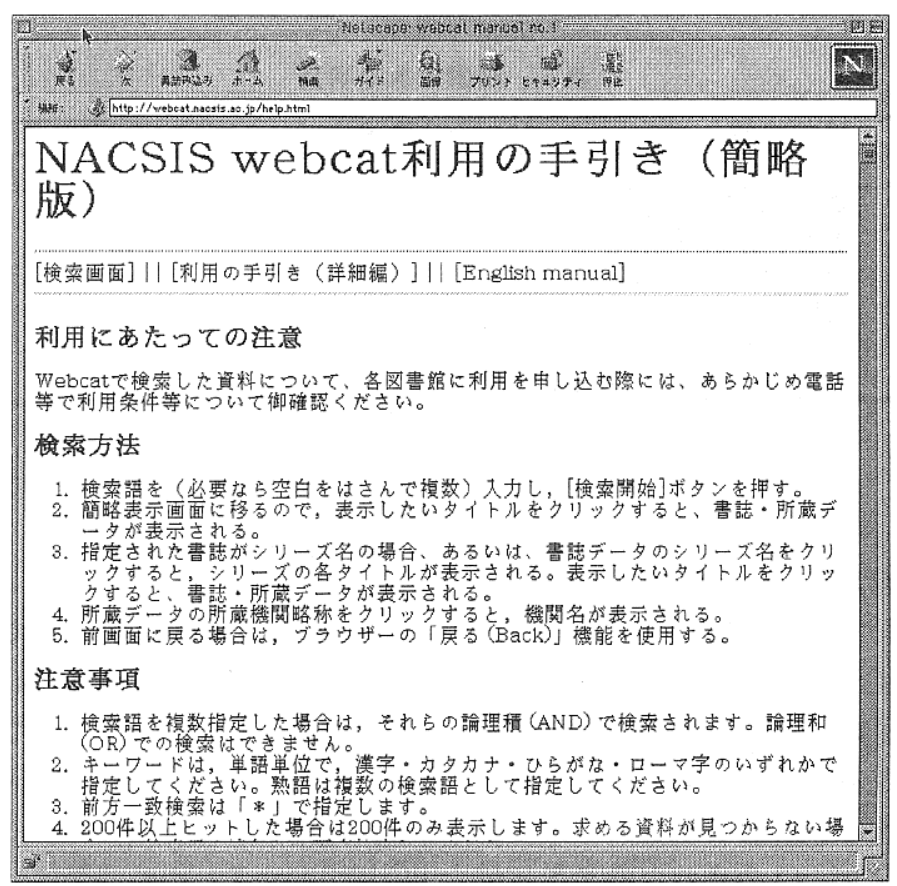

図 4 利用の手引き 


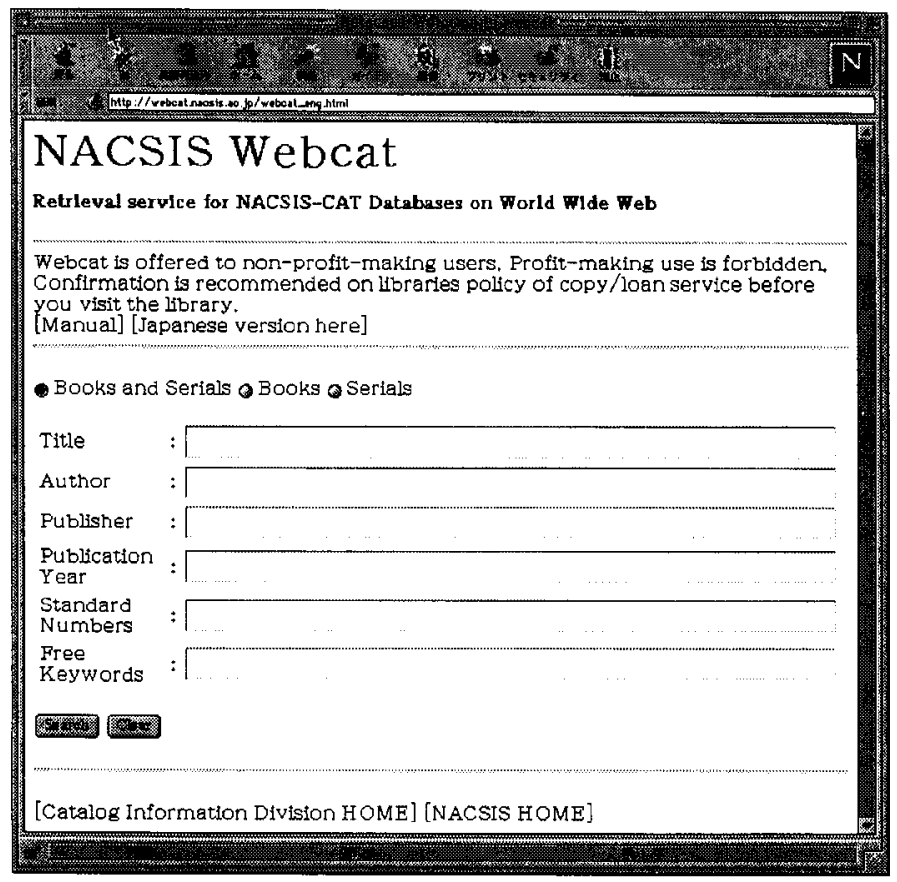

図 5 英語版検索画面

表 5 検索できる項目

\begin{tabular}{|c|c|c|c|c|}
\hline \multirow[t]{2}{*}{ 検索フィールド } & 険索対象 & \multicolumn{2}{|l|}{ 娭索方法 } & 前方一致 \\
\hline & & 萗全形 & キーワード & \\
\hline タイトル & 毒名、別名、シリーズ等 & O(和資料のみ) & 0 & $\mathrm{O}$ \\
\hline 著者名 & 著者、編者、翻訳者等 & & $\mathrm{O}$ & 0 \\
\hline 出版者 & 出版者、発行者等 & 0 & $x$ & $\mathrm{O}$ \\
\hline 出版年 & 出版年 & 0 & $x$ & 0 \\
\hline 標準番号 & ISBN,ISSN & 0 & $x$ & 0 \\
\hline フリーワード & タイトル、著者名、件名、分類等 & $x$ & 0 & 0 \\
\hline
\end{tabular}

\section{3 検索項目}

検索できる項目等は表 5 のとおりとなってい る。

Webcat では, NACSIS-CAT, NACSIS-IRに 比べて, 検索可能項目数は抑之られているが4)，一 般的に目録のデー夕を探す場合，頻繁に使用され る項目は備えられている。また, 各項目について前 方一致可能とすることで, 入力された検索キーが 不備であっても，検索もれを防ぐようにしている。

\section{Webcat $の$ 運用}

Webcatは24時間サービスを行っており，参照 しているデータベースは NACSIS-CAT で構貿 した総合目録データベースである。総合目録デ一 タベースはNACSIS-CATのサービス時間であ る, 月曜日から金曜日の 9：00〜20：00（木曜日 は18：00まで）の時間带は, 常にデータの追加, 修正，削除が行われている。 
NACSIS-CATに同時接続して作業を行って いる端末数は約 2,000 台。しかも, NACSIS-CAT は業務用のサービスであるだけに，レスポンスの 速さは非常に重要である。したがって，Webcatか らの不特定多数の利用者からの検索要求を, NACSIS-CATと同じマシンの同じデータベー スを使用して処理することは，避けねばならない。 そこで, Webcat では, バックアップ用として作成 していた別のデータベースを検珤専用のデータ ベースとして機能させることとした。さらにアク セスの制御のため別のマシンを用意し, NACSIS -CATへの影響がないよう配慮した。総合目録 データベースのバックアップは週に一度の頻度で 行うため, Webcat で参照するデータは, NACSIS

表 6 検索対象となるデータベースの切り替え

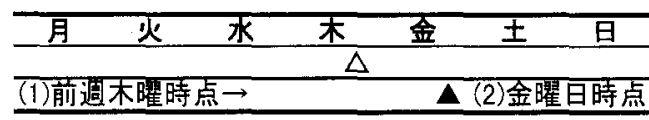

(1)CAT業務時間带 (月-金)

$\rightarrow$ バックアップDB(前週木曜日業務終了時 $\triangle の も の)$

(2)CAT業務時间外(土-日)

＼cjkstart業務用DB(直前の金曜日業務終了時 $\Delta$ のも)
CATより 1 週間前の状態になることもある。土 日はバックアップデータベースを更新するため, サービスを行っていない業務用のデータべースを 参照している。この切り替えは, 表 6 のように行っ ている5)。

\section{Webcat $の$ 利用状況}

試行サービスを開始した平成 9 年 4 月からの利 用状況を表 7 に示す。

試行サービス開始直後から，利用が急激に伸び ている。システムの負荷を抑えるため，大久的な 㕕報もしなかったので，各図書館による学内への 広報活動により, 研究者, 学生等へと利用が広がっ たと思われる。正式運用を開始してからの利用の 伸びはさらにめざましいものがある。夏休みに相 当する 7,8 月は, 試行开ービス中も同様の現象 が拈きだ，一旦利用は落ち込む。しかし，その 時期が過ぎると急激に伸びてくるであろうこと は，やはり試行サ一ビス時の利用状況からも推測 できる。

利用している機関は, NACSIS-CAT 等のユー ザでもある大学図書館が利用回数の上位に位椬し

表 7 利用状況の推移

検索回数の推移(日平均)

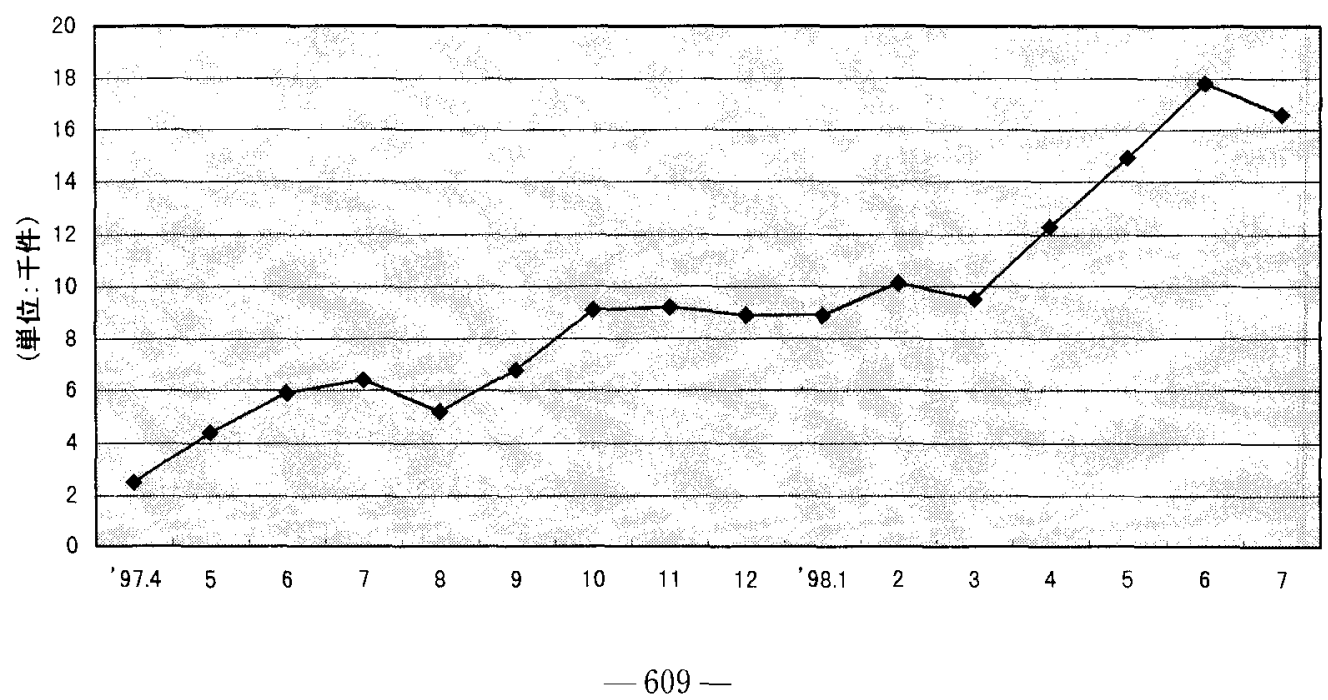


情報管理 Vol. $41 \quad$ No. $8 \quad$ Nov. 1998

ている。海外からの利用は, 平成10年 7 月の実績 ではおよそ40か国からのアクセスがあった。試行 サービス開始直後から，リンク依頼も多く寄せら れた。営利目的でなく，NACSISのサービスであ ることを明記するという条件を満たした上で，自 由にリンクしていただいている。

\section{Webcat の今後の課題}

\section{1 相互利用に関する情報の提供}

Webcatを通じて，資料の所在情報を獲得する ことのできた利用者の次の要求は，当然ながら資 料そのものである。NACSIS-CATは目録データ ベースであるがゆえに，資料の内容そのものは収 録していない。したがって，所在が確認できた後 は，利用者と各図書館との直接交涉が始まる。

研究者であれば, Webcat で検索した結果を, 自 分の属する図書館に依頼し，NACSIS-ILLを通 じて複写などを申し込むことができる。しかし， 学生や一般利用者がどのような利用ができるのか は，各図書館の方針によって異なるだけに，それ に関する情報を提供することも必要となる。Webcat から参照できる情報として，現在は各図書館 の名称, 住所, 電話番号等を公開しているのみな ので, 各図書館の利用条件等を知る手段としては, その罒書館のホームページを見つけてそこで探す か，あるいは直接問い合わせるしかない。もち万 ん, NACSIS-ILL 利用図書館については，利用条 件のデー夕も内部的には持っているが，あくまで も業務用として記述してあるものなので，そのま ま一般に公開することはなじまない。そこで，問 い合わせる利用者側, 回答する図書館側双方の手 間を省くため，別途公開用のデータを入力，ある いは既存のデータから編集するなどして，Webcatの検索の流れの中で，利用条件までを参照で きるようにするなどの方策が必要であろう。この 点については，情報の提供の方法から検討に入っ たところである。

\section{2 海外へのサービス}

海外からの利用に対する一層の配慮もこれから の課題である。検索画面や利用の手引きは英語版 も用意してあり，検索語の入力もローマ字が使用 可能にしてある。しかし, 書誌, 所蔵情報は原デー 夕のまま，つまり漢字のまま表示されるため，日 本語の知識がかなりなければ実際には利用しにく い。また，環境によっては，文字化けが発生する こともある。資料の確認ができても，利用条件の 確認などには, また日本語の壁がある。各図書館 の英語版のホームページにリンクをはって，そこ を参照してもらえると，すぐにも対応できるのだ が，すべての図書館がそういった情報を発信して いるわけではないので，さらに検討が必要である ことはいうまでもない。

\section{3 電子情報へのリンク}

総合目録データベースに登録されている資料の うち,内容そのものを Internet 上で公開している 資料も目立ち始めた。NACSISでも，オンライン ジャーナルなどと呼ばれるこれらの資料固有の情 報，つまりURLやアクセスのための必要条件等 を目録情報の中に取り込むことについて，検討を 進めている。これが実現するとここURL 情報は Webcatにも反映されることとなり，ブラウザの 機能を使えば，検索したその場でクリックして， 資料そのものにアクセスすることが可能となるで あろう。

\section{7. まと め}

前項にあげたようにWebcatにも問題はまだ まだある。しかし，利用者も順調に增之続け，利 用者からの便利だとの言葉をいただく機会も少な くないことを考えれば，非常に順調なスタートで あるといえよう。

このようなサービスが可能となったのは，十数 年に及ぶ，良質なデータの蓄積があったからこそ であろう。「良質な」というと手前みそのようだが， このデータべースのデータはすべて NACSIS 
-CATに参加している各図書館から登録してい ただいたものであり，品質のよいデータべースを 作成，維持するために日常の業務として他館との 連絡調整も頻繁に行われており，誤りや不足のあ るデータは日々修正されている。

「品質」にかけては，この規模のデータベース
としては相当手をかけているはずである。今後も， 機能や操作性の向上と合わせ, 質のよいデータを 提供しつづけることにより, Webcat 利用者の信 頼を得られるサービスとして運用をつづけていき たい。

\section{参 考 文 献 n m m m}

1）学術情報センター. 平成10年度文部省学術情 報センター要覧. 東京, 学術情報センター, 1998 2）学術情報センター. NACSIS Home Page (http://www.nacsis.ac.jp/nacsis.index. html)

3）学術情報センタ一. 学術雑誌総合目録欧文編 全国調査マニュアル．東京, 学術情報センター一,
1997

4) 米澤誠, 鵜沢和往. Webcat：総合目録デー夕 ベース WWW 検索サービス. 医学四書館. 45(2) 268-270 (1998)

5）学術情報センター. Webcat Q\&A. オンライ ンシステムニュースレター. 607 (1998) 